\title{
PENGARUH BUDAYA ORGANISASI, PENGALAMAN MENGAJAR DAN TINGKAT PENDIDIKAN TERHADAP PROFESIONALISME DOSEN UNIVERSITAS RIAU KEPULAUAN TAHUN AJARAN 2012/2013
}

\author{
FITRI YANTI \\ Dosen Tetap Pendidikan Sejarah FKIP Universitas Riau Kepulauan
}

\begin{abstract}
ABSTRAK
Penelitian ini bertujuan untuk mengetahui: (1). Pengaruh secara bersama-sama budaya organisasi, pengalaman mengajar dan tingkat pendidikan terhadap profesionalisme dosen Universitas Riau Kepulauan Batam, (2). Pengaruh budaya organisasi terhadap profesionalisme dosen Universitas Riau Kepulauan Batam, (3). Pengaruh pengalaman mengajar terhadap profesionalisme dosen Universitas Riau Kepulauan Batam, (3). Pengaruh tingkat pendidikan terhadap profesionalisme dosen Universitas Riau Kepulauan Batam.

Penelitian ini menggunakan metode survey dengan pendekatan kuantitatif yang dilakukan di Universitas Riau Kepulauan Batam. Populasi dalam penelitian ini adalah dosen tetap Universitas Riau Kepulauan Batam sebanyak 110 orang. Sedangkan sampelnya sebanyak 86 orang yang ditentukan dengan teknik proporsional simple random sampling berpedoman pada penentuan atau pendekatan Formula Taro Yamane. Instrumen yang digunakan untuk mengumpulkan data adalah angket. Teknik analisis data menggunakan analisis regresi ganda dengan prasyarat uji analisis menggunakan uji normalitas, linieritas dan uji multikolinieritas.

Berdasarkan hasil penelitian menunjukkan bahwa (1). terdapat pengaruh positif dan signifikan variabel budaya organisasi, pengalaman mengajar dan tingkat pendidikan terhadap profesionalisme dosen Universitas Riau Kepulauan Batam dengan sumbangan efektif sebesar $62,25 \%$ sehingga ada $37,75 \%$ yang tidak dapat dijelaskan dalam penelitian ini yang disumbangkan dari faktor lain. (2). Budaya organisasi berpengaruh positif dan signifikan terhadap profesionalisme dosen Universitas Riau Kepulauan Batam dengan sumbangan sebesar $62,25 \%$ artinya budaya organisasi dibangun secara efektif antara dosen dengan dosen, dosen dengan pimpinan serta dosen dengan mahasiswa. (3). Pengalaman mengajar tidak berpengaruh signifikan terhadap profesionalisme dosen Universitas Riau Kepulauan artinya pengaruh pengalaman mengajar terhadap profesionalisme dosen Universitas Riau Kepulauan masih relative kecil dengan sumbangan efektifnya sebesar $2,01 \%$. (4). Tingkat pendidikan tidak berpengaruh signifikan terhadap profesionalisme dosen Universitas Riau Kepulauan artinya pengaruh tingkat pendidikan terhadap profesionalisme dosen masih relatif kecil dengan sumbangan efektif sebesar $1,46 \%$.

Kata kunci: budaya organisasi, pengalaman mengajar, tingkat pendidikan, profesionalisme
\end{abstract}

\section{PENDAHULUAN}

\section{A. Latar Belakang}

Pendidikan yang berkualitas merupakan modal dasar sekaligus menjadi kunci keberhasilan pembangunan nasional. Hal ini telah dibuktikan oleh beberapa negara maju dan 
negara tetangga seperti Singapura, Thailand dan Korea Selatan. Ketiga Negara tersebut kini telah berkembang menjadi negara industri baru di Asia, bukan karena kekayaan alamnya, tetapi karena mutu tenaga kerjanya. Bila sumberdaya manusia Indonesia dalam jumlah besar seperti saat ini dapat ditingkatkan mutunya, maka diharapkan dalam waktu yang relative singkat, kehidupan masyarakat Indonesia dapat tumbuh secara mantap dan memberikan tingkat pendapatan nasional yang relative tinggi. Oleh karena itu, tantangan utama yang dihadapi sekarang ini dan untuk masa yang akan datang adalah mempersiapkan tenaga-tenaga kerja yang berkualitas terutama pelaksana pendidikan, bukan saja yang mampu dan terampil melakukan pekerjaan, tetapi juga mempunyai inovasi dan kreatifitas tinggi, serta mempunyai daya analisis yang jauh kedepan.

Dunia pendidikan memproduksi tenaga-tenaga yang berkualitas untuk berbagai jenis dan tingkatan keahlian. Dunia pendidikan khususnya pendidikan tinggi menghasilkan sarjana, yaitu tenaga-tenaga terpilih yang siap menjadi dinamisator pembangunan. Gerak dan laju pembangunan banyak ditentukan oleh jumlah mutu, kemampuan dan kesesuaian antara lulusan pendidikan tinggi dan kebutuhan nyata yang akan diserap oleh lapangan pekerjaan. Dunia pendidikan harus mampu mengeluarkan tenaga yang sesuai dengan kebutuhan masyarakat. Secara umum disebutkan bahwa program pendidikan disemua tingkat harus direncanakan berdasarkan kebutuhan tenaga kerja yang jelas (educational planning based on manpower requirements). Di pihak lain, dunia pendidikan juga dipengaruhi oleh permintaan masyarakat (social demand), walaupun permintaan masyarakat akan pendidikan tidak selalu sesuai dengan kebutuhannya.

Berbagai permasalahan kemudian timbul sehubungan dengan mutu pendidikan, khususnya pendidikan tinggi. Pada akhir tahun 2004, data pendidikan dunia menunjukkan terjadinya keterpurukan dan kemorosatan pendidikan tinggi di Indonesia. Dari data 500 pendidikan tinggi yang ada di dunia, tidak ada satupun pendidikan tinggi di Indonesia yang menjadi pendidikan tinggi terbaik (Efendi, 2005:43).

Rendahnya mutu pendidikan di Indonesia disebabkan oleh banyak faktor diantaranya adalah tingkat profesionalisme pendidik, kurikulum dan fasilitas sarana dan prasarana. Analisis data terakhir menunjukkan bahwa "pendidik/dosen" merupakan faktor kunci yang paling menentukan karena proses kegiatan belajar mengajar ditentukan oleh pendidik dan peserta didik (Falah Yunus, 2005:3). Hal ini mencerminkan betapa pentingnya peran pendidik (dosen) dalam meningkatkan mutu pendidikan tinggi.

Kota Batam sebagai kota industri juga mempunyai spirit yang kuat untuk mengembangkan pendidikan. Ini terbukti cukup banyak pendidikan tinggi yang eksis di daerah ini salah satunya adalah Universitas Riau Kepulauan (UNRIKA). Namun berdasarkan pengamatan penulis dosen-dosen di pendidikan tinggi ini sebagai tenaga profesional perlu lebih mengenal profesinya. Tidak sedikit dosen yang datang untuk mengajar tidak melakukan persiapan, bahkan untuk menyerahkan rencana pembelajaran kegiatan persemester (rpkps) ke mahasiswa pada awal perkuliahaan masih ada dosen yang menunda-nunda.. Di lain pihak, ada pula dosen yang hanya memberikan sejumlah bahan ajar dengan tidak mengindahkan apakah bahan itu dapat dipahami mahasiswa/peserta didiknya atau tidak, yang penting bahan ajar selesai diberikan. Ada juga dosen yang hanya mementingkan ilmu pengetahuan yang memberikan ilmunya ke peserta didik dengan tidak memikirkan apakah ilmu itu sesuai untuk diberikan atau tidak. Ada pula dosen yang menganggap dirinya paling pandai serta sebagai sumber kekuasaan sehingga apa yang dikatakannya itu adalah benar dan peserta didik harus mematuhinya. Padahal, 
dalam kenyataannya ilmu pengetahuan itu berkembang dan sumber informasi pun berkembang sehingga dosen bukan satu-satunya sumber informasi.

Permasalahan lainnya adalah masih rendahnya minat dosen untuk melakukan riset ilmiah karena keterbatasan pengetahuan, dana, serta daya saing. banyak dosen yang menghindarkan diri dari tugas utamanya sebagai pendidik dengan berbagai cara untuk menutupi kekurangannya. Misalnya dengan menerapkan "despotisme ilmiah" karena tidak mampu mengatasi dialog kritis dengan mahasiswa/peserta didik, lari dari topik utama perkuliahan untuk menghabiskan waktu karena tidak menguasai materi, atau memberi penugasan kemudian membiarkan para mahasiswa/peserta didik berdebat sendiri dengan alasan melatih mereka berdiskusi.

Kemudian dosen kebanyakan merasa sudah puas dengan gelar magister atau master yang didapat ataupun ada yang berkeinginan melanjutkan studi terikat dengan pekerjaan dan kebanyakan dosen telah bekerja di instansi lain sehingga terjadi "ambigu pekerjaan" dan sangat berpengaruh terhadap budaya kerja organisasi di kampus sehingga status dosen di Unrika dikelompokkan menjadi dosen tetap fulltime dan dosen tetap partime serta dosen tidak tetap (dosen luar biasa) sehingga penciptaan organisasi kampus yang baik belum kondusif. Hal inilah yang menjadi latar belakang penelitian tentang pengaruh budaya organisasi, pengalaman mengajar dan tingkat pendidikan, terhadap profesionalisme dosen Universitas Riau Kepulauan Batam. Tahun ajaran 2012/2013.

\section{B. Rumusan Masalah}

Berdasarkan latar belakang di atas, maka pokok permasalahan dalam penelitian ini adalah sebagai berikut :

1. Sejauhmana budaya organisasi, pengalaman mengajar dan tingkat pendidikan secara bersama-sama berpengaruh terhadap profesionalisme dosen Universitas Riau Kepulauan Batam?

2. Sejauhmana budaya organisasi berpengaruh terhadap profesionalisme dosen di Universitas Riau Kepulauan Batam?

3. Sejauhmana pengalaman mengajar berpengaruh terhadap profesionalisme dosen di Universitas Riau Kepulauan Batam?

4. Sejauhmana tingkat pendidikan berpengaruh terhadap profesionalisme dosen di Universitas Riau Kepulauan Batam?

\section{Tujuan Penelitian}

Untuk mengetahui pengaruh secara bersama-sama budaya organisasi, pengalaman mengajar dan tingkat pendidikan terhadap profesionalisme dosen Universitas Riau Kepulauan Batam.

1. Untuk mengetahui pengaruh budaya organisasi terhadap profesionalisme dosen Universitas Riau Kepulauan Batam.

2. Untuk mengetahui pengaruh pengalaman mengajar terhadap profesionalisme dosen Universitas Riau Kepulauan Batam.

3. Untuk mengetahui pengaruh tingkat pendidikan terhadap profesionalisme dosen Universitas Riau Kepulauan Batam

\section{KAJIAN PUSTAKA}

\section{A. Konsep Profesionalisme Dosen \\ 1.Pengertian Profesionalisme}

Profesional berasal dari kata profesi artinya satu bidang pekerjaan yang ingin atau akan ditekuni seseorang. Dalam undang-undang nomor 14 tahun 2005 disebutkan bahwa profesional adalah pekerjaan atau kegiatan yang dilakukan oleh seseorang dan menjadi 
sumber penghasilan kehidupan yang memerlukan keahlian, kemahiran atau kecakapan yang memenuhi standar mutu atau norma tertentu serta memerlukan pendidikan profesi.

Menurut Jamil (dalam Supriadi:1999:65) profesional menunjuk pada dua hal. Pertama, penampilan seseorang yang sesuai dengan tuntutan seharusnya. Kedua, kinerja dituntut sesuai standar yang telah ditetapkan. Jadi profesional kependidikan adalah orang yang melaksanakan tugas profesi kependidikan dengan penuh tanggung jawab dan dedikasi tinggi dengan sarana penunjang berupa bekal pengetahuan yang dimilikinya sesuai dengan standar yang telah ditetapkan.

Profesionalisme merupakan suatu tingkah laku, suatu tujuan atau rangkaian kualitas yang menandai atau melukiskan corak profesi. Profesionalisme juga diartikan sebagai suatu paham yang menciptakan dilakukannya berbagai kegiatan kerja tertentu dalam kehidupan masyarakat dengan berbekal keahlian yang tinggi dan berdasarkan pada rasa keterpanggilan jiwa denagan semangat untuk melakukan pengabdian memberikan bantuan layanan pada sesama manusia.

\section{Kompetensi Dosen}

Dalam rangka penyelenggaraan tri dharma pendidikan tinggi, dosen melaksanakan tiga jenis kegiatan, yaitu pendidikan dan pengajaran, penelitian, dan pengabdiaan kepada masyarakat. Sebagaimana disebutkan sebelumnya, bidang utama kegiatan dosen adalah melaksanakan pendidikan dan pengajaran. Namun demikian, kegiatan penelitian dan pengabdiaan masyarakat juga wajib dilaksanakan oleh seorang dosen. Kedua kegiatan ini akan sangat menunjang kegiatan pendidikan dan pengajaran yang lebih baik (Direktorat Penelitian dan Pengabdiaan pada Masyarakat, 2002).

Sebagai profesional, dosen dituntut memiliki sejumlah kompetensi agar dapat melaksanakan tugasnya dengan baik. Kompetensi yang dibahas berikut ini hanya berkaitan dengan tugas utama dosen, yaitu menyelenggarakan pendidikan dan pengajaran. Jadi, kompetensi yang dimaksud adalah kompetensi dosen sebagai pengajar.

Di masyarakat, telah dikenal adanya Sepuluh Kompetensi Pendidik. Sementara itu, Depdiknas (2002) juga mengembangkan profil kompetensi pendidik yang secara substantif tidak berbeda dengan Sepuluh Kompetensi Pendidik yang telah ada sebelumnya. Karena baik pendidik maupun dosen pada hakikatnya mengemban tugas yang sama, profil kompetensi pendidik tersebut dapat diaplikasikan pada dosen.

Kompetensi dosen yang dipaparkan di sini mengacu pada profil kompetensi pendidik yang dikembangkan oleh Depdiknas (2002). Kompetensi ini terdiri atas empat rumpun, yaitu penguasaan bidang studi, pemahaman peserta didik, penguasaan pembelajaran yang mendidik, dan pengembangan kepribadian dan keprofesionalan.

Kompetensi bidang studi mencakup dua hal, yaitu penguasaan disiplin ilmu dan penguasaan kurikuler. Penguasaan disiplin ilmu berkaitan dengan substansi dan metodologi keilmuaan. Penguasaan kurikuler berhubungan dengan pemilihan, penataan, pengemasan, dan representasi materi yang sesuai dengan kebutuhan peserta didik.

Kompetensi pemahaman tentang peserta didik diperlukan dalam memberikan layanan pendidikan yang berorientasi kepada peserta didik. Sebagai seorang pendidik, dosen harus memahami kondisi awal mahasiswa/peserta didik dan kondisi akhir yang ditargetkan. Kondisi peserta didik yang dimaksudkan disini adalah dapat berupa pengetahuan dan keterampilan. Untuk mengetahui kedua kondisi ini, dosen dituntut memiliki penguasaan terhadap prinsipprinsip pengukuran dan evaluasi (kompetensi evaluasi). Di samping itu, dosen juga harus memahami adanya perbedaan individu di antara para mahasiswa/peserta didik. Perbedaan 
individu ini antara lain meliputi perbedaan intelektual, emosional, spiritual, sosial, budaya, ekonomi, politik, dan gaya belajar. Pada dasarnya, setiap mahasiswa/peserta didik merupakan individu yang unik yang menuntut adanya pelayanan yang berbeda.

Kompetensi pengembangan kepribadian dan keprofesionalan mencerminkan kemampuan profesional dosen untuk dapat mengetahui, mengukur, dan mengembang-mutakhirkan kemampuannya secara mandiri. Dalam hal ini, dosen senantiasa dituntut untuk mengikuti perkembangan keilmuan, baik yang berkenaan dengan bidang studi (subject matter) maupun yang berkenaan dengan pedagogik (pedagogical content knowledge). Kedua bidang ilmu sangat dibutuhkan oleh dosen yang memiliki tugas utama mengajar ( Grossman:1991). Seorang dosen harus berprakarsa dan bertanggung jawab menjajagi berbagai cara perolehan informasi untuk mengembangmutakhirkan kemampuan secara mandiri. Untuk keperluan tersebut, dapat dilakukan, misalnya, melalui kerja sama dengan sejawat dan masyarakat. Sebagai profesional yang berkepribadian, seorang dosen dalam melaksanakan tugasnya selalu berorientasi pada kemaslahatan mahasiswa/peserta didik. Jadi, orientasinya pada pemenuhan kebutuhan mahasiswa/peserta didik yang bertanggung jawab dan manusiawi.

\section{B. Budaya Organisasi}

Budaya organisasi didefinisikan oleh Andrew Pettrew dalam Achmad Sobirin sebagai" The system of such publicly and collectively accepted meanings operating for given group at a given time", dimana diartikan budaya sebagai system makna yang diterima secara terbuka dan kolektif yang berlaku untuk waktu tertentu bagi sekelompok orang tertentu.

Budaya organisasi memiliki dampak pada efisiensi dan efektifitas organisasi. Oleh karena itu, budaya organisasi merupakan bagian penting dalam memahami organisasi seluruhnya. McKenna dan Beech berpendapat bahwa: "Budaya yang kuat mendasari aspek kunci pelaksaan fungsi organisasi dalam hal efisiensi, inovasi, kualitas serta mendukung reaksi yang tepat untuk membiasakan mereka terhadap kejadian-kejadian, karena etos yang berlaku mengakomodasikan ketahanan. Sedangkan menurut Ndraha (2003:123) mengungkapkan bahwa "Budaya kuat juga bisa dimaknakan sebagai budaya yang dipegang secara intensif, secara luas dianut dan semakin jelas disosialisasikan dan diwariskan dan berpengaruh terhadap lingkungan dan perilaku manusia". Budaya yang kuat akan mendukung terciptanya sebuah prestasi yang positif bagi anggotanya dalam hal ini budaya yang diinternalisasikan pihak pimpinan akan berpengaruh terhadap sistem Perilaku para pendidik dan staf dibawahnya baik didalam organisasi maupun diluar organisasi.

Menurut pendapat Silalahi (2004:8), budaya organisasi harus diarahkan pada penciptaan nilai (Values) yang pada intinya faktor yang terkandung dalam budaya organisasi, artinya harus mencakup faktor-faktor antara lain : keyakinan, nilai, norma, gaya, kredo dan keyakinan terhadap kemampuan pekerja. Untuk mewujudkan tertanamnya budaya organisasi tersebut harus didahului oleh adanya integrasi atau kesatuan pandangan barulah pendekatan manajerial bisa dilaksanakan antara lain berupa:

a. Menciptakan bahasa yang sama dan warna konsep yang muncul.

b. Menentukan batas-batas antar kelompok.

c. Distribusi wewenang dan status.

d. Mengembangkan syariat, tharekat dan ma'rifat yang mendukung norma kebersamaan.

e. Menentukan imbalan dan ganjaran

f. Menjelaskan perbedaan agama dan ideologi.

g. Budaya dengan profesionalisme 
Dalam perkembangan berikutnya dapat dilihat ada keterkaitan antara budaya dengan disain organisasi sesuai dengan design culture yang akan diterapkan. Untuk memahami disain organisasi tersebut (McKenna, et.al, 2002:65) membagi empat tipe budaya organisasi:

a. Budaya kekuasaan (Power culture)

Budaya ini lebih memfokuskan sejumlah kecil pimpinan menggunakan kekuasaan yang lebih banyak dalam cara memberi perintah. Budaya kekuasaan juga dibutuhkan dengan syarat mengikuti esepsi dan keinginan anggota suatu organisasi.

Seorang karyawan butuh adanya peraturan dan pemimpin yang tegas dan benar dalam menetapkan seluruh perintah dan kebijakannya. Karena hal ini menyangkut kepercayaan dan sikap mental tegas untuk memajukan institusi organisasi. Kelaziman yang masih menganut manajemen keluarga, peranan pemilik institusi begitu dominan dalam pengendalian sebuah kebijakan terkadang melupakan nilai profesionalisme yang justru hal inilah salah satu penyebab jatuh dan mundurnya organisasi.

b. Budaya peran (Role culture)

Budaya ini ada kaitannya dengan prosedur birokratis, seperti peraturan organisasi dan peran/jabatan/posisi spesifik yang jelas karena diyakini bahwa hal ini akan menstabilkan sistem. Keyakinan dan asumsi dasar tentang kejelasan status/posisi/peranan yang jelas inilah akan mendorong terbentuknya budaya positif yang jelas akan membantu menstabilkan suatu organisasi. Hampir semua orang menginginkan suatu peranan dan status yang jelas dalam organisasi.

c. Budaya pendukung (Support culture)

Budaya dimana didalamnya ada kelompok atau komunitas yang mendukung seseorang yang mengusahakan terjadinya integrasi dan seperangkat nilai bersama dalam organisasi tersebut. Selain budaya peran dalam menginternalisasikan suatu budaya perlu adanya budaya pendukung yang disesuaikan dengan kredo dan keyakinan anggota dibawah. Budaya pendukung telah ditentukan oleh pihak pimpinan ketika organisasi/institusi tersebut didirikan oleh pendirinya yang dituangkan dalam visi dan misi organisasi tersebut. Jelas didalamnya ada keselarasan antara struktur, strategi dan budaya itu sendiri. Perubahan bisa terjadi dengan menanamkan budaya untuk belajar terus menerus (longlife education).

d. Budaya prestasi (Achievement culture)

Budaya yang didasarkan pada dorongan individu dalam organisasi dalam suasana yang mendorong eksepsi diri dan usaha keras untuk adanya independensi dan tekananya ada pada keberhasilan dan prestasi kerja. Budaya ini sudah berlaku dikalangan akademisi tentang independensi dalam pengajaran, penelitian dan pengabdian serta dengan pemberlakuan otonomi kampus yang lebih menekankan terciptanya tenaga akademisi yang profesional, mandiri dan berprestasi dalam melaksanakan tugasnya.

\section{Pengalaman Mengajar}

a. Pengertian Pengalaman Mengajar

Pengertian pengalaman menurut (Suwardi Notosudairjo, 1990:289), adalah apa yang sudah dialami dalam kurun waktu yang lama. Dalam Acmad Sugandi (2004:7), mengajar adalah seperangkat peristiwa (events) yang mempengaruhi peserta didik sedemikian rupa sehingga peserta didik itu memperoleh kemudahan. Jadi pengalaman mengajar adalah apa yang sudah dialami dalam mengajar di organisasi berkenaan dengan kurun waktu

Selain berorientasi pada waktu lamanya pendidik/dosen menggeluti profesinya, pengaman mengajar juga mengandung asumsi bertambahnya kompetensi pendidik/dosen seiring perjalankan waktu lamanya pendidik/dosen menjalakan profesinya. Dengan demikian 
pengalaman mengajar juga mengandung arti seberapa banyak intesitas pendidikan dan latihan ( diklat ) yang pernah diikuti dalam rangka peningkatan kompetensi pendidik baik di tingkat kecamatan, kabupaten, provinsi, nasional maupun internasional. Menurut Depdiknas (2010) pendidikan yang diikuti dalam rangka pengembangan dan / atau peningkatan kompetensi selama melaksanakan tugas sebagai pendidik baik pada tingkat kecamatan, kabupaten /kota, provinsi, nasional, maupun internasional baik yang relevan maupun kurang rik eleven dengan kompetensi kualifikasi pendidik.

Pengalaman mengajar merupakan salah satu faktor dalam mendukung pelaksanaan kegiatan belajar mengajar. Pengalaman mengajar yang memiliki menjadi penentu pencapaian hasil belajar yang akan diraih oleh peserta. Pengalaman mengajar yang cukup, dalam arti waktu yang telah dilalui oleh seorang pendididk dalam melaksanakan tugasnya akan mendukung pencapain hasil belajar sebagai tujuan yang akan diraih oleh instansi.

Pengalaman mengajar merupakan suatu hal yang menjadikan perhatian yang tidak kalah pentingnya dalam menentukan kinerja pendidik/dosen. Pendidik/dosen yang mempunyai pengalaman mengajar yang kurang memadai, maka kurang mendukung keberhasilan kinerjanya.

Dari definisi di atas maka pengalaman mengajar dapat diasumsikan segala sesuatu yang telah dialami seorang pendidik selama menjalankan tugas kependidikannya dalam waktu yang cukup lama.

b. Pengalaman Mengajar dan profesionalisme.

Pengalaman mengajar merupakan salah satu Faktor dalam mendukung pelaksanaan kegiatan belajar mengajar. Pengalaman mengajar yang dimiliki oleh seorang pendidik/dosen menjadi penentu pencapaian hasil belajar yang akan diraih oleh peserta didik. Pengalaman mengajar yang cukup, dalam arti waktu yang telah dilalui oleh seorang pendidik dalam melaksanakan tugasnya akan mendukung pencapaian hasil belajar sebagai tujuan yang akan diraih oleh organisasi.

Pengalaman mengajar merupakan suatu hal yang menjadikan perhatian yang tidak kalah pentingnya dalam menentukan kinerja. Dosen yang mempunyai pengalaman yang memadai secara positif akan mendukung kinerjanya. Sebaliknya Jika pengalaman mengajaranya tidak memadai maka tentu kurang mendukung kinerjanya.

\section{Tingkat Pendidikan}

\section{a. PengertianTingkat Pendidikan}

Menurut Suwardi Notosudirjo (1990; 311), tingkat pendidikan adalah tahapan pendidikan yang ditetapkan berdasarkan tingkat perkembangan peserta didik, tujuan yang akan dicapai dan kemampuan yang dikembangkan.

Pendidikan di Indonesia mengenal tiga jenjang pendidikan yaitu pendidikan dasar (SD/MI/Paket A dan SMP/MTS/ Paket B, pendidikan menengah, (SMA, SMK/Paket C) dan pendidikan tinggi (Pendidikan Tinggi). Meski tidak termasuk jenjang pendidikan terdapat pula pendidikan anak usia dini, pendidikan yang diberikan sebelum memasuki pendidikan dasar.

\section{b. Jenjang-Jenjang Pendidikan}

1) Pendidikan dasar

Pendidikan ini merupakan pendidikan awal selama 9 tahun pertama masa organisasi anak-anak dimulai dari organisasi dasar dan organisasi menengah pertama. Pada masa ini para peserta didik mempelajari bidang-bidang studi antara lain ilmu pengetahuan alam, matematika, ilmu pengetahuan sosiala, Bahasa Indonesia, bahasa inggris, pendidikan seni, pendiidkan olah raga (Fuad ihsan, 1997:26) 
2) Pendidikan Menengah

Pendidikan menengah merupakan lanjutan pendidikan dasar terdiri atas pendidikan menengah umum dan pendidikan menengah kejuruan. Pendidikan menengah berbentuk organisasi menegaha atas, madrasah aliyah, organisasi menengah kejuruan dan bentuk lain yang sederajat seperti paket $\mathrm{C}$

3) Pendidikan Tinggi

Pendidikan tinggi merupakan lanjutan dari organisasi menengah dan menjadi pendidikan tertinggi dari ketiga tingkat pendidikan yang ada. Gelar yang didapat pada pendidikan tinggi menurut hirarkinya adalah diploma III ditempuh selama 3 tahun masa pendidik S1 ditempuh selama 4 tahun dan S2 ditempuh setelah bergelar S1 serta S3 ditempuh setelah jenjang S2.

\section{METODE PENELITIAN}

\section{A. Jenis Penelitian}

Metode yang digunakan dalam penelitian ini adalah metode penelitian survey dengan pendekatan kuantitatit Pada pelaksanaan penelitian ini dilakukan penelitian korelasi kuatnya hubungan antar variabel bebas dan variabel terikat dengan metode analisis korelasi dan melakukan prediksi persamaan garis yang sesuai dengan analisis regresi linear.

\section{B. Lokasi, Populasi dan Sampel Penelitian}

\section{Lokasi dan waktu penelitian}

Penelitian ini dilaksanakan di Universitas Riau Kepulauan Batam yang terdiri dari 5 (lima) Fakultas yaitu Fakultas Keguruan dan Ilmu Pendidikan (FKIP), Fakultas Teknik (FT), Fakultas Ekonomi (FE), Fakultas Ilmu Politik dan Sosial (FISIPOL) dan Fakultas Hukum (FH).

\section{Populasi dan Sampel}

Populasi dalam penelitian ini adalah seluruh dosen tetap Universitas Riau Kepulauan sebanyak 110 orang. Dalam pengambilan sampel penelitian digunakan metode proporsional simple random sampling maka dengan pendekatan formula Taro Yamane sebagai berikut:

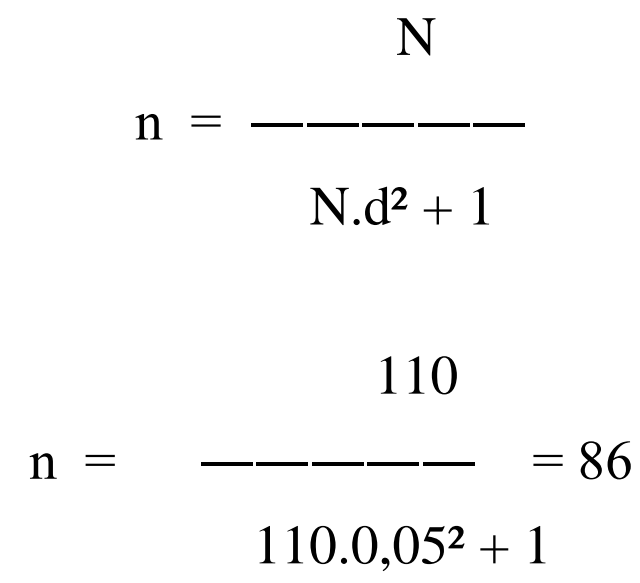

Keterangan:

$\mathrm{N}=$ Jumlah anggota populasi 


\section{$\mathrm{n}=$ Jumlah anggota sampel \\ $\mathrm{d}=$ Taraf signifikasi yang diinginkan (maksimal 0,05)}

\section{Teknik Pengumpulan Data}

Teknik pengumpulan data dalam peneltian ini adalah observasi, dokumentasi dan angket. Dosen-dosen tetap Universitas Riau Kepulauan diberikan seperangkat pertanyaan tertulis atau angket untuk diisi sesuai dengan keadaan dan kondisi yang sebenarnya.

1. Penyusunan instrumen Penelitian

Penyusunan instrumen dalam penelitian ini dilakukan dalam beberapa tahapan sebagai berikut:

a). Menyusun indikator dari variabel penelitian

b). Menyusun kisi-kisi instrumen

c).menyusun instrumen berdasarkan kisi-kisi

d). Melakukan validasi isi dan revisi berdasarkan masukan dari para ahli

e). Melakukan uji coba instrumen

f). Menentukan bukti validitas dan estimasi reliabilitas instrumen

g).melakukan revisi instrumen

Kisi-kisi instrument meliputi budaya organisasi, pengalaman mengajar, pendidikan dan profesionalisme dosen. Selanjutnya disusun instrumen budaya organisasi, pengalaman mengajar, pendidikan dan profesionalisme dosen.

\section{Teknik Pengelolahan Data}

Menurut Suharsini arikunto (2005:97) instrumen penelitian adalah alat atau fasilitas yang digunakan oleh peneliti dalam mengumpulkan data agar pekerjaannya lebih mudah dan lebih baik dalam arti yang lebih cermat, lengkap dan sistematis yang mudah diolah.

Variasi inetrumen yang baik harus mempunyai dua persyaratan yaitu valid dan reliabel.

\section{Uji Validitas}

Untuk menentukan validitas soal peneliti menggunakan rumus Pearson Product Moment yaitu:

$$
r_{x y}=\frac{N\left(\sum X Y\right)-\left(\sum X\right) \cdot\left(\sum Y\right)}{\sqrt{\left\{N \cdot \sum x^{2}-\left(\sum x\right)^{2}\right\} \cdot\left\{N \sum Y^{2}-\left(\sum Y\right)^{2}\right\}}}
$$

Keterangan:

$\mathrm{r}_{\mathrm{xy}}=$ Koefisien korelasi antara variabel $\mathrm{X}$ dan variabel $\mathrm{Y}$, dua variabel yang dikorelasi

$\sum \mathrm{X}=$ Jumlah skor butir soal

$\sum \mathrm{Y}=$ Jumlah skor total

$\mathrm{N}=$ Jumlah peserta tes

\section{Uji reliabilitas}

Menurut Suharsimi Arikunto (2006:178) uji realibilitas adalah suatu instrumen yang cukup dapat dipercaya untuk dapat digunakan sebagai pengumpul data karena instrumen tersebut 
sudah baik. Uji reliabilitaas menunjukkan sejauh mana suatu instrumen dapat memberikan hasil pengukuran yang konsisten apabila pengukuran dilakukan berulang-ulang. Uji ini diujicobakan pada subjek penelitian. Pengukuran reliabilitas dilakukan menggunakan rumus Alpha Cronbach berikut :

$$
r_{11}=\left[\frac{k}{k-1}\right]\left[1-\frac{\sum \sigma_{b}^{2}}{\sigma_{t}^{2}}\right]
$$

\section{Keterangan:}

$$
\begin{array}{ll}
r_{11} & =\text { reliabilitas yang dicari } \\
\mathrm{k} & =\text { banyaknya soal } \\
\sum \sigma_{b}^{2} & =\text { jumlah varian butir } \\
\sigma_{t}^{2} & =\text { varians total }
\end{array}
$$

Dikatakan reliabilitas jika antara korelasi yang diperoleh $>r_{\text {tabel }}$ taraf signifikansi $5 \%$. Dikatakan tidak realibel jika angka korelasi $<r_{\text {tabel }}$ pengujian. Reliabilitas dalam penelitian ini menggunakan program SPSS versi 20.0.

\section{Uji Prasyarat Analisis}

a. Uji Multikulinearitas

Uji multikulinieritas dapat dideteksi dengan menghitung koefisien ganda dan membandingkannya dengan koefisien korelasi antar variable bebas. Model regresi yang baik seharusnya tidak terjadi korelasi yang sempurna diantara variabel bebas. Salah satu cara untuk mendeteksi adanya multikulinearitas adalah dengan melihat tolerance atau varians Inflation Factor (VIF). Apabila tolerance lebih kecil dari 0,1 atau nilai VIF diatas 10, maka terjadi multikulinearitas. Jika hasil tolerance pada masing-masing variabel lebih besar dari 0,1 sedangkan nilai Varians Inflation Factor (VIF) lebih kecil dari 10 sehingga model regresi dalam penelitian ini tidak ada masalah multikulinearitas.

b. Uji Normalitas Data

Uji normalitas dilakukan untuk mengetahui normal tidaknya distribusi data. Adapun pengujian normalitas ini menunjuk Sudjana (2002:466-467), langkah-langkahnya sebagai berikut :

1) Hipotesis

$\mathrm{H}_{0}=$ sampel dari populasi berdistribusi normal

$\mathrm{H}_{1}=$ sampel dari populasi tidak berdistribusi normal

2) Prosedur Pengujian Hipotesis

a) $X_{1}, X_{2}, X_{3}, \ldots, X_{n}$ dijadikan bilangan baku $Z_{1}, Z_{2}, \ldots, Z_{n}$ dengan rumus:

$$
Z_{i}=\frac{X_{i}-\bar{X}}{S}
$$

$$
\text { dimana } Z_{i}=\text { Bilangan baku }
$$

Keterangan:

$Z=$ Angka Baku

$\bar{X}=$ Rata-rata

$\mathrm{S}=$ Simpangan baku sampel

Dari data sampel diurutkan dari skor terendah ke skor tertinggi.

b) Dengan data distribusi normal baku, dihitung peluang:

$F\left(Z_{i}\right)=P\left(Z_{i} \geq Z\right)$.

c) Menghitung proporsi skor baku $Z_{1}, Z_{2}, \ldots, Z_{n} \leq Z$ dinyatakan dengan: $S\left(Z_{i}\right)$ 
Maka $S\left(Z_{i}\right)=\frac{\text { banyaknya } Z_{1}, Z_{2, \cdots}, Z_{n,} \leq Z_{i},}{n}$

d) Menghitung selisih antara $F\left(Z_{i}\right)-S\left(Z_{i}\right)$ dan menentukan harga mutlaknya.

e) Mengambil harga yang terbesar dari harga mutlak selisih tersebut, diberi simbol $L_{0}$.

f) Kesimpulan

Dalam penentuan ditolak atau diterima ditentukan dengan kriteria:

(1) Jika $L_{\text {ohitung }}>L_{\text {tabel }}$ maka $\mathrm{H}_{0}$ diterima sebagai distribusi sebaran data tidak normal.

(2) Jika $L_{\text {Ohitung }}<L_{\text {tabel }}$ maka $\mathrm{H}_{0}$ diterima sebagai distribusi sebaran data normal.

Pengujian uji normalitas butir soal dalam penelitian ini menggunakan bantuan SPSS versi 20.0 .

c. Uji Linieritas Data

Uji Linieritas ini dimaksudkan untuk mengetahui apakah model persamaan yang diperoleh cocok atau tidak. Adapun menurut Sudjana (2002 : 330-337) adalah sebagai berikut :

1) $\mathrm{F}_{\text {hitung }}=\frac{R J K_{r c}}{R J K_{E}}$

2) $\mathrm{F}_{\text {tabel }} \quad=(1-\alpha)(\mathrm{k}-2 ; \mathrm{N}, \mathrm{k}) \mathrm{s}$

3)Menghitung :

a) Jika $F_{\text {hitung }}>F_{\text {tabel }}$, maka $\mathrm{H}_{0}$ ditolak berarti persamaannya tidak linier

b) Jika $\mathrm{F}_{\text {hitung }}<\mathrm{F}_{\text {tabel, }}$ maka $\mathrm{H}_{0}$ diterima berarti persamaannya linier. Pengujian uji linieritas dalam penelitian ini menggunakan bantuan program SPSS versi 20.0

\section{Teknik Analisis Data}

a. Regresi Linier Berganda

Digunakan untuk mengetahui pengaruh budaya organisasi, pengalaman mengajar dan tingkat pendidikan terhadap profesionalisme dosen Unrika.

Adapun menurut Sudjana (2002: 69) rumusnya adalah:

$Y=\alpha+b_{1} X_{1}+b_{2} X_{2}+b_{3} X_{3}$

Keterangan :

$Y \quad=$ profesionalisme dosen

$\alpha \quad=$ konstanta

$b_{1}=$ koefesien regresi untuk $\mathrm{X}_{1}$

$b_{2}=$ koefesien regresi untuk $\mathrm{X}_{2}$

$b_{2} \quad=$ koefesien regresi untuk $\mathrm{X}_{3}$

$X_{1} \quad$ = budaya organisai

$X_{2} \quad=$ pengalaman mengajar

$X_{3}=$ tingkat pendidikan

b. Uji F

Uji $\mathrm{F}$ dilakukan untuk mengetahui signifikansi pengaruh variabel budaya organisasi $\left(\mathrm{X}_{1}\right)$, pengalaman mengajar $\left(\mathrm{X}_{2}\right)$, dan tingkat pendidikan $\left(\mathrm{X}_{3}\right)$ secara bersama-sama terhadap profesionalisme dosen (Y).

1) Menentukan formula Ho dan $\mathrm{H}_{1}$

Ho : $\beta=0$ : berarti tidak ada pengaruh antara budaya organisasi $\left(\mathrm{X}_{1}\right)$ dan pengalaman mengajar $\left(\mathrm{X}_{2}\right)$ dan tingkat pendidikan $\left(\mathrm{X}_{3}\right)$ terhadap profesionalisme dosen $(\mathrm{Y})$

$\mathrm{H}_{1}: \beta \neq 0$ : berarti ada pengaruh antara budaya organisasi $\left(\mathrm{X}_{1}\right)$ pengalaman mengajar $\left(\mathrm{X}_{2}\right)$ dan tingkat pendidikan $\left(\mathrm{X}_{3}\right)$ terhadap profesionalisme dosen $(\mathrm{Y})$

2) Penentuan Level of significant $5 \%$, dipilih $\alpha=0,05$

3) Kriteria pengujian 
Ho diterima apabila : $F_{\text {hitung }} \leq \mathrm{F}_{\text {tabel }}$

$\mathrm{H}_{1}$ ditolak apabila : $\mathrm{F}_{\text {hitung }} \geq \mathrm{F}_{\text {tabel }}$

4) Perhitungan nilai $\mathrm{F}$

$$
F=\frac{J K R / k}{J K G /(n-k-1)}
$$

Dengan :

$\mathrm{JKR}=\mathrm{b}_{1} \sum \mathrm{x}_{1} \mathrm{y}+\mathrm{b}_{2} \sum \mathrm{x}_{2} \mathrm{y}$

$\mathrm{JKT}=\sum \mathrm{y}^{2}$

$\mathrm{JKG}=\mathrm{JKT}-\mathrm{JKR}$

Dimana : $K=$ jumlah variabel independen

$\mathrm{n}=$ jumlah sampel

$\mathrm{F}=\mathrm{F}_{\text {hitung }}$

5) Kesimpulan

Nilai $\mathrm{F}_{\text {hitung }}$ diperoleh kemudian dibandingkan dengan $\mathrm{F}_{\text {tabel. }}$. Maka dapat diketahui ada tidaknya pengaruh variabel budaya organisasi $\left(\mathrm{X}_{1}\right)$, pengalaman mengajar $\left(\mathrm{X}_{2}\right)$ dan tingkat pendidikan $\left(\mathrm{X}_{3}\right)$ secara bersama-sama terhadap profesionalisme dosen $(\mathrm{Y})$. Uji F dilakukan dengan menggunakan bantuan program SPSS for windows 20.0.

\section{c. Uji Parsial (Uji t)}

Digunakan untuk mengetahui signifikasi ada tidaknya pengaruh variabel bebas terhadap variabel terikat secara parsial atau sendiri-sendiri, sehingga sudah bisa diketahui apakah dugaan yang sudah ada dapat diterima atau tolak. Langkah-langkahnya :

1) Menentukan formula Ho dan $\mathrm{H}_{1}$

Ho : $\beta=0$ : berarti tidak ada pengaruh antara variabel independen dengan variabel dependen secara terpisah

$\mathrm{H}_{1}: \beta \neq 0$ : berarti ada pengaruh antara variabel independen dengan variabel dependen secara terpisah

2) Level of significant $\alpha=5 \%$

3) Kriteria pengujian

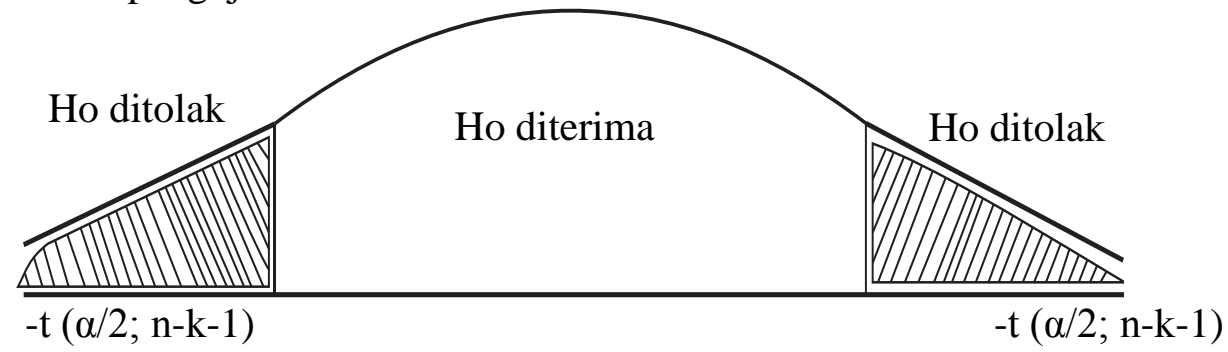

Diterima apabila $-\mathrm{t}_{\text {tabel }} \leq \mathrm{t}_{\text {hitung }} \leq \mathrm{t}_{\text {tabel }}$

Ho ditolak apabila $t_{\text {hitung }}>t_{\text {tabel }}$ atau $t_{\text {hitung }}>-t_{\text {tabel }}$

4) Pengujian nilai $t$ 


$$
\begin{aligned}
t & =\frac{b i}{S b i} \text { sudjana }(2003: 70-94 \\
S b i & =\sqrt{\frac{S^{2} y \cdot 12}{\sqrt{\sum X_{i j}^{2}\left(1-R i^{2}\right)}}} \\
S_{\mathrm{y} .12}^{2} & =\frac{J K(S)}{(n-k-1)}
\end{aligned}
$$

Keterangan :

Sbi = galat baku koefesien bi

$S^{2}$ y. $12=$ galat baku taksiran dalam populasi

$\mathrm{Ri}^{2}=$ koefesien antara $\mathrm{X}_{1}$ dan $\mathrm{X}_{2}$

5) Kesimpulan

Membandingkan antara $t_{\text {hitung }}$ dengan $t_{\text {tabel }}$, maka dapat diketahui ada tidaknya pengaruh budaya organisasi $\left(\mathrm{X}_{1}\right)$ terhadap profesinalisme dosen $(\mathrm{Y})$. Dilakukan untuk variabel $\mathrm{X}_{1}$, $\mathrm{X}_{2}$, dan $\mathrm{X}_{3}$ secara parsial terhadap variabel $\mathrm{Y}$.

Pengujian uji t dilakukan dengan menggunakan bantuan program SPSS versi 20.0.

\section{HASIL PENELITIAN DAN PEMBAHASAN}

\section{A. Interpretasi Hasil Pengujian Hipotesis}

Melakukan interpretasi hasil analisis penelitian, yaitu melakukan penafsiran terhadap pengujian hipotesis. Walaupun hasil analisis statistik itu sendiri sudah merupakan suatu kesimpulan, tetapi belum memadai tanpa ada interpretasi yang dikaitkan dengan perumusan masalah. Interpretasi dan pengujian hipotesis diuraikan sebagai berikut:

1) Ada pengaruh yang signifikan budaya organisasi terhadap profesionalisme dosen

Besarnya pengaruh variabel budaya organisasi $\left(\mathrm{X}_{1}\right)$ terhadap profesionalisme dosen $(\mathrm{Y})$ yang dihitung dengan koefisien korelasi adalah 0.782 atau $\left(\mathrm{rx}_{1} \mathrm{y}=0.782\right)$. Sedangkan uji signifikansi ditemukan bahwa $\mathrm{t}_{\text {hitung }} \geq \mathrm{t}_{\text {tabel }}$ atau $11.758>1.663$, maka signifikan. Hal ini menunjukkan adanya pengaruh antara budaya organisasi secara signifikan terhadap profesionalisme dosen. Hasil uji signifikansi ini menunjukkan bahwa terdapat korelasi yang signifikan pada variabel independen $\mathrm{X}_{1}$ terhadap variabel dependen $\mathrm{Y}$, yang berarti terdapat kontribusi yang signifikan budaya organisasi dengan profesionalisme dosen di Universitas Riau Kepulauan Batam.

2) Tidak ada pengaruh pengalaman mengajar terhadap profesionalisme dosen

Besarnya pengaruh variabel pengalaman mengajar $\left(\mathrm{X}_{2}\right)$ terhadap profesionalisme $(\mathrm{Y})$ yang dihitung dengan koefisien korelasi adalah 0,014 atau $\left(\mathrm{rx}_{2} \mathrm{y}=0.014\right)$. Sedangkan uji signifikansi ditemukan bahwa nilai $\mathrm{t}_{\text {tabel }}=1.663$, ternyata $\mathrm{t}_{\text {hitung }}\left\langle\mathrm{t}_{\text {tabel }}\right.$ atau 1.663$\rangle$ 1.312, maka dapat dikatakan tidak signifikan. Hasil uji siginifikansi ini menunjukkan bahwa terdapat pengaruh yang tidak signifikan antara variabel independen $\mathrm{X}_{2}$ terhadap variabel dependen $\mathrm{Y}$, yang berarti tidak terdapat kontribusi yang signifikan pengalaman mengajar terhadap profesionalisme dosen di Universitas Riau Kepulauan Batam.

3) Tidak ada pengaruh tingkat pendidikan terhadap profesionalisme dosen

Besarnya pengaruh variabel tingkat pendidikan $\left(\mathrm{X}_{3}\right)$ terhadap profesionalisme $(\mathrm{Y})$ yang dihitung dengan koefisien korelasi adalah 0,024 atau $\left(\mathrm{rx}_{3} \mathrm{y}=0.024\right)$. Sedangkan uji signifikansi ditemukan bahwa nilai $t_{\text {tabel }}=1.663$, ternyata $t_{\text {hitung }}<\mathrm{t}_{\text {tabel }}$ atau 1.663$\rangle$ 1.117, maka dapat dikatakan tidak signifikan. Hasil uji siginifikansi ini menunjukkan 
bahwa terdapat pengaruh yang tidak signifikan antara variabel independen $\mathrm{X}_{3}$ terhadap variabel dependen $\mathrm{Y}$, yang berarti tidak terdapat kontribusi yang signifikan tingkat pendidikan terhadap profesionalisme dosen di Universitas Riau Kepulauan Batam.

4) Ada pengaruh yang Signifikan budaya organisasi, pengalaman mengajar dan tingkat pendidikan secara bersama-sama terhadap profesionalisme dosen.

Pengaruh secara bersama-sama antara variabel budaya organisasi $\left(X_{1}\right)$, pengalaman mengajar $\left(\mathrm{X}_{2}\right)$ dan tingkat pendidikan $\left(\mathrm{X}_{3}\right)$ terhadap profesionalisme dosen $(\mathrm{Y})$ diperoleh harga koefisien korelasinya adalah $\mathrm{R}=0.789$ atau $\mathrm{Rx}_{1} \mathrm{x}_{2} \mathrm{x}_{3} \mathrm{y}=0.789$ (nilai $\mathrm{R}=0.789$ ini diperoleh dari tabel Model Summary kolom kedua R dari hasil pengolahan data dengan program SPSS 20). Sedangkan uji F untuk melihat signifikansinya ditemukan bahwa F hitung $>\mathrm{F}_{\text {tabel }}$, atau $45.53>3.09$, maka signifikan. Hasil uji-F ini menunjukkan bahwa terdapat pengaruh yang signifikan pada variabel independen $X$ terhadap variabel dependen Y, yang berarti terdapat kontribusi yang signifikan antara budaya organisasi, pengalaman mengajar dan tingkat pendidikan dengan profesionalisme dosen di Universitas Riau Kepulauan Batam.

\section{B. Pembahasan Hasil Penelitian}

Berdasarkan hasil pengujian yang diuraikan oleh beberapa peneliti dan para ahli terbukti bahwa budaya organisasi, pengalaman mengajar dosen dan tingkat pendidikan berkontribusi terhadap profesionalisme dosen

1. Budaya organisasi berpengaruh positif dan signifikan terhadap profesionalisme.

Berdasarkan kajian hasil penelitian ditemukan kontribusi sebesar $62.25 \%$ budaya organisasi terhadap profesionalisme dosen, hal ini diperkuat dengan koefisien korelasi sebesar 0.789 atau $\left(\mathrm{rx}_{1} \mathrm{y}=0.789\right)$. yang kemudian didapat uji signifikansi budaya organisasi dengan profesionalisme dosen didapatkan $\mathrm{t}_{\text {hitung }} \geq \mathrm{t}_{\text {tabel }}$ atau $11.758>1.663$, hal ini menunjukkan signifikansi yang sangat baik. Hal tersebut selaras dengan pendapat Moeljono $(2003 ; 17)$ menjelaskan budaya kerja, tampaknya tidak dapat dipisahkan dengan budaya organisasi, budaya korporat. Dimana budaya kerja menjadi nilai-nilai dominan yang disebarluaskan di dalam organisasi dan menjadi acuan filosofi kerja karyawan. Budaya organisasi akan mendukung proses kerja yang diharapkan. Silalahi $(2004 ; 37)$ mengambarkan sebuah konsep dimana budaya organisasi merupakan landasan dalam menjalankan budaya kerja, budaya kerja yang disampaikan ini dapat diterminologikan sebagai pengerucutan profesionalisme dosen dalam menjalankan sistem pengajaran dalam kampus, lebih jelasnya menurut Silalahi digambarkan sebagai berikut :

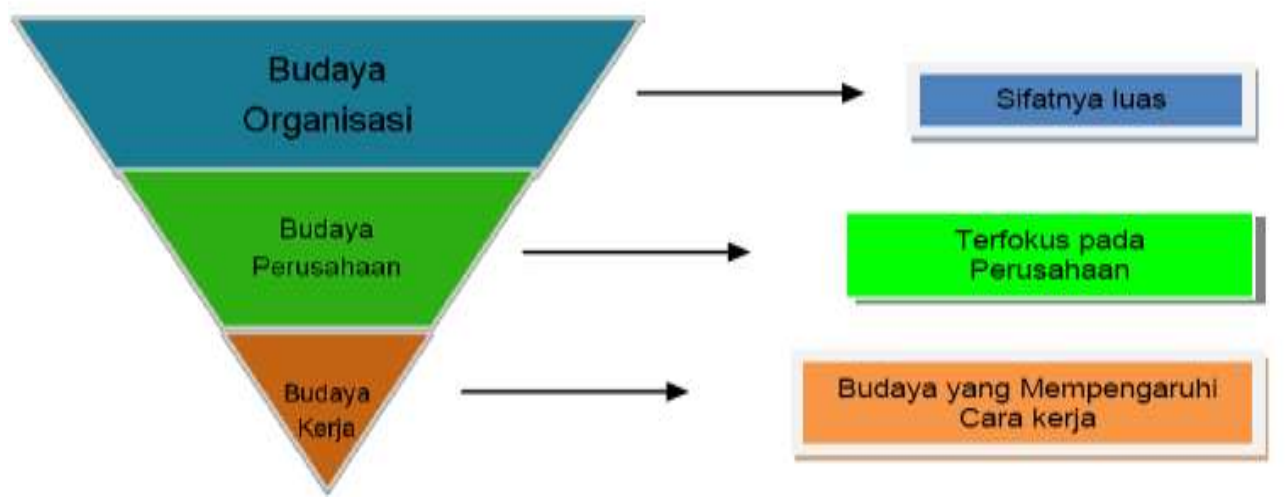

Gambar 5. Bangunan Budaya organisasi, Budaya Perusahaan dan Budaya Kerja 
Disamping itu secara riil dilapangan kondisi sebagian besar dosen di Unrika banyak berkecimpung pada bidang organisasi antara lain ADI (Asosiasi Dosen Indonesia). Interaksi yang terjadi dalam ADI akan membuka pola pikir perkembangan profesionalisme dosen ditinjau dari komponen profesionalisme. Hasil ini juga selaras dengan hasil penelitian yang dilakukan oleh Siwi Astuti (2012) yang menyimpulkan bahwa budaya organisasi, kepemimpinan kepala organisasi dan motivasi secara bersama-sama berpengaruh terhadap kinerja pendidik SMP di Kokap, Kolon Progo. Konteks kinerja ini dapat disejajarkan dengan profesionalisme.

2. Pengalaman Mengajar Berkontribusi Sangat Rendah Terhadap Profesionalisme Dosen. Berdasarkan kajian hasil penelitian ditemukan bahwa pengalaman mengajar dosen berkontribusi sebesar $2.01 \%$, yang diperkuat dengan bukti koefisien korelasi pengalaman mengajar terhadap profesionalisme dosen sebesar 0,142 atau $\left(\mathrm{rx}_{2} \mathrm{y}=0.142\right)$. Sedangkan uji signifikansi ditemukan bahwa nilai $\mathrm{t}_{\text {tabel }}=1.663$, ternyata $\mathrm{t}_{\text {hitung }}<\mathrm{t}_{\text {tabel }}$ atau $1.663>1.312$, dikatakan bahwa hasil yang didapatkan dari uji signifikansi tersebut tidak signifikan atau menunjukkan adanya korelasi yang sangat rendah antara pengalaman mengajar terhadap profesionalisme dosen. Sekalipun terdapat hubungan yang lemah terhadap profesionalisme dosen akan tetapi pengalaman mengajar masih memberikan pengaruhnya, hal ini dikuatkan dengan pendapat Looney (2003) juga cenderung berpihak kepada pengalaman mengajar mempengaruhi tingkat pengajaran tenaga pengajar. Melanjutkan tentang kajiannya (Looney 2003), berpendapat bahwa memang terdapat hubungan yang signifikan, tetapi lemah antara pengalaman dengan keberhasilan tenaga pengajar. Hal ini juga dikuatkan oleh pendapat Hoy dan Woolfolk (1993) yang mengatakan bahwa pengalaman mengajar tidak memberi pengaruh secara statistik terhadap keberhasilan tenaga pengajar, konteks keberhasilan tenaga pengajar ini dapat disejajarkan dengan profesionalisme dosen. Kondisi yang ada di lingkungan Universitas Riau Kepulauan adalah pengalaman yang dimiliki oleh setiap dosen tidak menjamin seseorang profesional. Pengalaman mengajar tiap individu dalam pengajaran tidak sama. Pengalaman mengajar dapat ditinjau dari banyak faktor, misalnya umur dan organisasi masyarakat yang diikuti. Dari faktor umur misalnya sebagian besar dosen Unrika masih tergolong usia muda, sehingga pengalaman mengajar dosen unrika dapat dikatakan masih kurang, tentu hal ini akan mempengaruhi profesionalismenya.

3. Tingkat Pendidikan Berkontribusi Sangat Rendah Terhadap Profesionalisme Dosen

Berdasarkan dari hasil penelitian didapatkan kontribusi tingkat pendidikan terhadap profesionalisme dosen sebesar, $1.46 \%$, kemudian diperkuat dengan hasil koefisien korelasinya adalah sebesar 0,121 atau $\left(\mathrm{rx}_{3} \mathrm{y}=0.121\right)$. Sedangkan uji signifikansi ditemukan bahwa nilai $\mathrm{t}_{\text {tabel }}=1.663$, ternyata $\mathrm{t}_{\text {hitung }}<\mathrm{t}_{\text {tabel }}$ atau $1.663>1.117$, maka dapat dikatakan tidak signifikan. Hal ini menunjukkan adanya pengaruh yang sangat rendah antara tingkat pendidikan terhadap profesionalisme dosen. Seharusnya tingkat pendidikan akan sangat berpengaruh atau berhubungan dengan profesionalisme seperti pendapat Caplow yang dikutip oleh Arsyad (1997) yang menyatakan bahwa semakin tinggi tingkat pendidikan seseorang maka semakin ada kecenderungan untuk sukses di dalam kerjanya, kemudian seperti yang disampaikan dalam Permen PAN, No.17 tahun 2013 pasal 24, bahwa jabatan akademik dosen harus memenuhi syarat berijazah paling rendah magister (S2). Berdasarkan hasil penelitian walaupun jenjang pendidikan dosen Unrika yang sebagian besar S2 namun hal itu hanya memberikan kontribusi yang rendah sehingga masih membutuhkan pengolahan dan pengembangan diri melalui organisasi, pengalaman atau lama mengajar. Saat ini pengembangan diri menuju profesionalisme masih kurang dikembangkan, misalnya masih 
kurangnya pengembangan profesionalisme melalui pelatihan/seminar yang diikuti oleh dosen Unrika Batam

4. Budaya organisasi, Pengalaman Mengajar dan Tingkat Pendidikan Secara Bersama-sama Berpengaruh positif dan signifikan Terhadap Profesionalisme Dosen.

Berdasarkan hasil penelitian yang didapatkan, terdapat kontribusi sebesar $62.25 \%$, yang diperkuat dengan hasil koefisien korelasi $\mathrm{R}=0.789$ atau $\mathrm{Rx}_{1} \mathrm{x}_{2} \mathrm{x}_{3} \mathrm{y}=0.789$ (nilai $\mathrm{R}=0.789$ ), kemudian dengan melakukan uji $\mathrm{F}$ untuk melihat signifikansinya ditemukan bahwa $\mathrm{F}_{\text {hitung }}>$ $\mathrm{F}$ tabel, atau $45.53>3.09$, maka signifikan. Hasil uji-F ini menunjukkan bahwa terdapat pengaruh yang signifikan pada variabel independen $\mathrm{X}$ terhadap variabel dependen $\mathrm{Y}$, yang berarti terdapat kontribusi yang signifikan antara budaya organisasi, pengalaman mengajar dan tingkat pendidikan dengan profesionalisme dosen di Universitas Riau Kepulauan Batam. Sejalan dengan temuan penelitian yang menghubungkan antara ketiga variabel terikat dan varibel bebas, yaitu antara budaya organisasi, pengalaman mengajar dan tingkat pendidikan terhadap profesionalisme dosen, maka profesionalisme sangat didukung oleh adanya budaya organisasi, pengalaman mengajar dan tingkat pendidikan dosen, hal ini dapat ditarik kesimpulan bahwa ketiga komponen yang digabungkan secara bersamaan akan sangat mendukung profesionalisme dosen dalam hubunganya menjalankan tugas dan fungsinya sebagai tenaga pengajar pada pendidikan tinggi. Pola pikir dalam budaya organisasi akan membangun pengalaman mengajar, yang diterapkan dalam proses kegiatan sehari-hari sebagai dosen, kemudian ditunjang dengan pendidikan yang selaras, maka segala kemampuan yang didapat dari organisasi dan pengalaman pengajaran didukung pola pikir dari hasil jenjang pendidikan akan sangat bermakna sekali terhadap tingkat profesionalisme dosen yang bersangkutan. Temuan penelitian ini sejalan dengan McLagan (1989) mengidentifikasi 25 kompetensi yang harus dimiliki oleh dosen dalam 'Models for HRD Practice' Kompetensi tersebut kemudian diklasifikasian menjadi 4 kelompok yaitu kompetensi teknik, kompetensi bisnis, kompetensi interpersonal, dan kompensi intelektual. Soft skill menjadi bagian dari kompetensi HRD profesional tersebut yang termuat dalam kompetensi interpersonal. Leach (1999) menguji kembali model yang dikembangkan oleh McLagan dan menemukan 23 kompetensi yang masih relevan untuk menyiapkan tenaga dosen yang profesional. Dua puluh lima kompetensi dosen yang dikembangkan dalam Models for HRD Practice adalah: (1) keterampilan menulis, (2) keterampilan berpresentasi, (3) kompetensi komputer, (4) keterampilan menyiapkan tujuan, (5) keterampilan mencari informasi, (6) keterampilan berproses dalam kelompok, (7) keterampilan bertanya, (8) keterampilan memberi feedback, (9) pemahaman tentang pembelajaran orang dewasa, (10) keterampilan menjalin hubungan, (11) keterampilan mengevaluasi, (12) keterampilan mewujudkan visi, (13) keterampilan mereduksi data, (14) keterampilan pelatihan, (15) keterampilan memilih media, (16) keterampilan mengidentifikasi kompetensi, (17) keterampilan meneliti, (18) keterampilan negosiasi, (19) perilaku organisasi, (20) teori pengembangan karier, (21) teori pengembangan dan pelatihan, (22) keterampilan sistem elektronik, (23) teori pengembangan organisasi, (24) penganggaran dan keterampilan mengelola sumber-sumber, dan (25) memahami bisnis. Diantara 25 komponen profesional dosen yang telah disebutkan diatas secara jelas telah dibuktikan dalam penelitian yng dijalankan ini.

\section{KESIMPULAN DAN SARAN}

\section{A. Kesimpulan}


Dari hasil analisis data dan pembahasan hasil penelitian terhadap dosen tetap Universitas Riau Kepulauan, maka dapat diambil beberapa kesimpulan sebagai berikut:

1. Budaya organisasi, pengalaman mengajar dan tingkat pendidikan secara bersamasama berpengaruh positif dan signifikan terhadap profesionalisme dosen di Universitas Riau kepulauan, artinya apabila budaya organisasi, pengalaman mengajar dan tingkat pendidikan ditingkatkan secara bersama-sama, maka akan berpengaruh positif dan signifikan terhadap profesionalisme dosen di Universitas Riau Kepulauan dengan sumbangan efektif secara bersama-sama 62,25\%. Dengan demikian ada $37,75 \%$ yang tidak dapat dijelaskan dalam penelitian ini namun berasal dari faktor lain.

2. Budaya organisasi berpengaruh positif dan signifikan terhadap profesionalisme dosen di Universitas Riau Kepulauan. Artinya apabila budaya organisasi dibangun secara efektif antara dosen dengan dosen, dosen dengan pimpinan dan dosen dengan mahasiswa maka akan berpengaruh positif dan signifikan terhadap profesionalisme dosen Universitas Riau Kepulauan dengan sumbangan efektif sebesar 62,25\%.

3. Meskipun menunjukkan harga positif, pengalaman mengajar ternyata tidak berpengaruh signifikan terhadap profesionalisme dosen di Universitas Riau Kepulauan. Artinya pengaruh pengalaman mengajar terhadap profesionalisme dosen Universitas Riau Kepulauan masih relative kecil dengan sumbangan efektifnya sebesar $2,01 \%$.

4. Tingkat pendidikan terhadap profesioanalisme dosen Universitas Riau Kepulauan Batam meski menunjukkan harga positif, ternyata tidak berpengaruh signifikan terhadap profesionalisme dosen artinya pengaruh tingkat pendidikan terhadap profesionalisme dosen masih relative kecil dengan sumbangan efektif sebesar $1,46 \%$.

\section{B. Implikasi}

Ketiga komponen ini, budaya organisasi, pengalaman mengajar dan tingkat pendidikan ketika digabungkan secara bersamaan akan sangat mendukung profesionalisme dosen di Universitas Riau Kepulauan dalam hubungan menjalankan tugas dan fungsinya sebagai tenaga pengajar pada pendidikan tinggi. Namun berdasarkan analisa statistik pada variabel pengalaman mengajar dan tingkat pendidikan tidak berpengaruh signifikan terhadap profesionalisme dosen di Universitas Riau Kepulauan, maka peran aktif dosen dalam pembelajaran dan mencari kesempatan menambah pengalaman serta studi lanjut harus ditingkatkan supaya berpartisipasi terhadap profesionalisme dosen.

\section{Saran-Saran}

Berdasarkan hasil penelitian yang diperoleh, maka diajukan saran-saran sebagai berikut:

1. Untuk Universitas Riau kepulauan Batam, bahwa sangat perlu peningkatan profesionalisme dosen secara continiu dan simultan melalui starategi dan kebijakan yang mendukung serta harus ada aturan yang jelas dan tegas dalam hal kebijakan yang menyangkut tentang profesionalisme dosen ke depan.

2. Memberi peluang lebih besar kepada dosen untuk pengembangan diri dalam proses pembelajaran sehingga pengalaman lebih bertambah termasuk dengan mengikuti pelatihan, seminar, loka karya yang berhubungan dengan profesioanlisme dosen serta peluang menenpuh pendidkan yang lebih tinggi.

3. Untuk dosen, agar tetap menciptakan budaya organisasi yang kondusif dan konsisten termasuk terhadap pimpinan 
4. Para dosen harus lebih arif dalam memandang profesi dosen serta berusaha meningkatkan kompetensi melalui peningkatan pendidikan, menambah pengalaman mengajar dan kegiatan lainnya yang mendukung profesionalisme dosen.

\section{DAFTAR PUSTAKA}

Arikunto Suharsimi, (1997), Prosedur Penelitian Suatu Pendekatan Praktek, Jakarta: PT Rineka Cipta.

Arsyad, A. (1997). Media Pembelajaran. Jakarta: PT Raja Grafindo Persada

Davis, Keith dan John W. Newstrom, (1995), Perilaku dalam Organisasi, $\quad$ (Terjemahan Agus Darma), Jakarta: Erlangga.

Depdiknas, (2002), Kebijaksanaan Teknis dan Program pengembangan pendidikan menengah umum di masa depan. Jakarta: Depdiknas.

E. Mulyasa, (2009), Menjadi Kepala organisasi Profesional, Bandung: PT Remaja Rosdakarya.

E.Mulyasa, (2007), Menjadi Pendidik Profesional, Bandung : PT Remaja Rosdakarya.

Fachruddin Saudagar,2009. Pengembangan profesionalitas pendidik, Gaung persada (GP Press); Jakarta.

Fathoni Abdurrahmat, (2006), Organisasi dan Manajemen Sumber Daya Manusia, Jakarta : PT Rineka Cipta

Gomez Meija, D.B. Balkin dan R.L. Cardy, (2001) Managing Human Resources, USA: Prentice Hall.

Hoy, W.K. \& Woolfolk, A.E. 1993. Teachers' sense of efficacy and the organizational health of schools. The Elementary School Journal 93(4): 356-372. 
Husen, Umar, (2004), Riset Sumber Daya Manusia, Jakarta: Gramedia Pustaka Utama.

Istijanto, (2005), Riset Sumber Daya Manusia, Yogyakarta : STIE YPKN

Kerlinger, Fred. N. ( 2004), Asas-Asas Penelitian Behavioral, Yogyakarta:Gajah Mada University Press.

Komariah, Aan. (2006). Visionary Leadership menuju sekolah dasar efektif. Jakarta: Bumi Aksara

Leach, J. A. (1999). Preparing tomorrow's HRD profesionals: Perceived relevance of the 1989 competency model. Journal of Vocational and Technical Education. 15(2). Spring, 1999. Di akses dari http://scholar.lib.vt.edu/ejournals/JVTE pada tanggal 1 Oktober 2013

Looney, L. 2003. Understanding Teachers' Efficacy Beliefs: The Role of Profesional Community. Doctoral Dissertation. University of Maryland.

Mangkunegara, Anwar Prabu, (2005), Manajemen Sumber Daya Manusia, Bandung : PT Remaja Rosdakarya.

McLagan, P. A. (1989). Model for HRD practice, Alexandria, VA: American Society for Training and Development.

McKenna, Eugene, (2000), How to built a corporate culture. Harvard Business school Publishing.

Miftah Toha, (2003), Kepemimpinan dalam Manajemen, Jakarta: PT Raja Grapindo.

Moeljono, Djokosantoso. (2003), Budaya Koorporat dan Keuggulan Korporasi, Jakarta: PT Elex Media Komputindo Gramedia.

Nawawi, Hadari, (2005), Manajemen Sumber Daya Manusia, Yogyakarta: Gajah Mada University Press.

Permenpan No.17 Tahun 2013.Jabatan Fungsional Dosen dan Angka Kreditnya. Diakses dari http://luk.staff.ugm.ac.id/atur/Permenpan17-2013JafungDosen.pdf. pada tanggal 1 Oktober 2013

Rivai, Veithzal, (2004), Kepemimpinan dan Prilaku Organisasi, Jakarta: PT Raja Grafindo Persada.

Robbin Stephen P, (2001), Organizational Behavior, New Jersey: Prentice Hall International.

Ruki, Ahmad S. (2001). Sistem Manajemen Kinerja. Jakarta: Penerbit Gramedia Pustaka Utama. 
Sedarmayanti, (2009), Sumber Daya Manusia dan Produktivitas Kerja, Bandung: CV Mandar Maju.

Sidik Priadana, (2005), Panduan Penyusunan Skripsi dan Tesis, Bandung: STIE Pasundan.

Siagian, Sondang P. (2002), Kiat Meningkatkan Produktivitas Kerja, Jakarta: Rineka Jaya. ( 2009 ) Metode Penelitiaan Pendidikan Bandung Alfabeta.

Sillalahi, Bennet. (2004). Corporate Culture and Performance Appraisal, Budaya Perusahaan dan Penilaian Unjuk Kerja, Jakarta: Yayasan Pendidikan Al-Hambra.

Sujana, (2005), Metode Statistika, bandung : CV Tarsito.

Sukardi, (2007), Metodologi Penelitian Pendidikan, Jakarta: PT Bumi Aksara.

Supriadi, (1999), mengangkat citra dan martabat guru. Jakarta: Adicitra Karya Nusa

Timple, Dale A, (2000), Seri Kepemimpinan Manajemen Sumber Daya Manusia, Jakarta: PT Elex Media Komputindo.

Yulk Garry, (2005), Kepemimpinan dalam Organisasi, Jakarta: PT Yudeks. 